Francisco Panzera ${ }^{1}$

Ruben Pérez 1

Paula Nicolini 1

Sonia Hornos 1

Jane Costa 2

Érika Borges 3

Liléia Diotaiuti 3

Christopher J. Schofield 4

\section{Chromosome homogeneity in populations of Triatoma brasiliensis Neiva 1911 (Hemiptera - Reduviidae - Triatominae)}

\author{
Homogeneidade cromossômica em populações \\ de Triatoma brasiliensis Neiva 1911 \\ (Hemiptera - Reduviidae - Triatominae)
}

\footnotetext{
1 Sección Genética Evolutiva, Facultad de Ciencias.

Iguá 4225 esq. Mataojo, Casilla de Correos 18110 ,

11400 Montevideo, Uruguay. panzera@fcien.edu.uy

2 Coleção Entomológica, Departamento de

Entomologia, Instituto

Oswaldo Cruz,

Fundação Oswaldo Cruz.

Av. Brasil 4365, CP 926,

Rio de Janeiro, $R J$

21045-900, Brazil.

3 Centro de Pesquisas

René Rachou, Fundação

Oswaldo Cruz.

CP 1743, Belo Horizonte, MG 30190-002, Brasil.

${ }_{4}^{4}$ Department of Infectious and Tropical Diseases,

London School of Hygiene and Tropical Medicine. London WCI E7TH, UK
}

\begin{abstract}
Triatoma brasiliensis is the most important vector of Chagas disease in the semiarid zone of the Northeast of Brazil. Several authors have reported the occurrence of four chromatic patterns with morphological, ecological, and genetic differences. In order to determine the existence of cytogenetic differentiation between these chromatic forms, we analyzed their karyotypes and the chromosome behavior during the male meiotic process. Triatoma brasiliensis shows distinct and specific chromosome characteristics, which differ from those observed in all other triatomine species. However, no cytogenetic differences were observed between the four chromatic forms of $\mathrm{T}$. brasiliensis. The lack of chromosome differentiation among them could indicate that the populations of this species are in a process of differentiation that does not involve their chromosomal organization.
\end{abstract}

Key words Chagas Disease; Triatominae; Triatoma brasiliensis; Cytogenetics; Karyotyping

Resumo Vários autores têm reportado a ocorrência de quatro padrões cromáticos e diferentes padrões morfológicos, genéticos e ecológicos de Triatoma brasiliensis no semi-árido nordestino do Brasil, região onde é o mais importante vetor da doença de Chagas. Para verificar diferenças citogenéticas nessas populações, foram analisados seus cariótipos e o comportamento cromossomial durante o processo meiótico em exemplares machos. Observou-se que o T. brasiliensis mostra características cromossômicas distintas e específicas entre as quatro populações, diferindo daquelas observadas em outras espécies de triatomíneos. No entanto, diferenças citogenéticas não foram observadas entre as quatro populações de $\mathrm{T}$. brasiliensis, o que poderia indicar que as referidas populações ainda se encontram em uma etapa inicial do processo de diferenciação, ainda não envolvendo a organização cromossomial.

Palavras-chave Doença de Chagas; Triatominae; Triatoma brasiliensis; Citogenética; Cariotipagem 


\section{Introduction}

Triatoma brasiliensis is distributed exclusively in Brazil and is considered the most important Chagas disease vector of the northeastern area of this country (Silveira et al., 1984). This species has a wide geographic distribution, including eleven States of Brazil. Three subspecies were described on the basis of chromatic characters of the pronotum, leg, and hemelytron (Galvão, 1956): T. brasiliensis brasiliensis Neiva, 1911 (from Caicó, Rio Grande do Norte), T. brasiliensis melanica Neiva \& Lent, 1941 (from Espinosa, Minas Gerais), and T. brasiliensis macromelasoma Galvão, 1956 (from Petrolina, Pernambuco). Lent \& Wygodzinsky (1979) considered these subspecies as synonymous based on the fact that intermediate forms seem frequent. Recently, a fourth chromatic pattern was collected in Juazeiro (Bahia), named as "juazeiro population" (Costa et al., 1997a).

Besides the variation of the cuticle color patterns, other differences were reported between the four forms of T. brasiliensis:

1) The brasiliensis populations have the most widespread distribution (Maranhão, Piauí, Ceará, Rio Grande do Norte, and Paraíba) and occupy a great variety of ecotopes (both domiciliary and wild). The macromelasoma and juazeiro populations were reported only from Pernambuco and Bahia, respectively, occupying peridomiciliary and sylvatic ecotopes. The melanica population, from the North of Minas Gerais, was only captured in sylvatic ecotopes (Costa et al., 1998).

2) Two populations, macromelasoma and juazeiro, were not found to be infected with Trypanosoma cruzi, whereas the brasiliensis and melanica populations had infection rates of $15 \%$ and $6.6 \%$, respectively (Costa et al., 1998).

3) Isoenzymatic data, based on nine loci, suggest a clear genetic differentiation between these populations. Nei's genetic distance reaches values corresponding to those found at the interspecific level for other species of Triatominae (Costa et al., 1997a). The greatest distance was obtained between the brasiliensis and melanica populations.

4) Recent DNA analysis of a region of the mitochondrial cytochrome B gene shows a large degree of sequence divergence, ranging from 2.7 (for the brasiliensis-macromelasoma pair) to $11.2 \%$ (for the brasiliensis-melanica pair) (Monteiro et al., 1999). The differences in DNA composition observed between some populations of $T$. brasiliensis is even higher than those found between other closely related triatomine species, such as Triatoma infestans/Triatoma platensis (7.7\%).
5) Scanning electron microscopy and morphometric measures of the eggs showed significant differences (Costa et al., 1997b).

6) Each population showed stability and homogeneity of their chromatic pattern for several years in laboratory colonies (Costa et al., 1996). Intermediate forms reported by Lent \& Wygodzinsky (1979) were not observed either in the field or in the laboratory.

7) Reciprocal crosses among all populations showed the F1 fertile. However, in the F2, a high percentage of sterile eggs, longer development period, and high mortality rate of fifth instar nymphs were observed for the brasiliensis male x melanica female (Costa, 1999).

In order to determine the existence of chromosome differentiation between these chromatic forms, we analyzed them in terms of cytogenetic characters previously used to differentiate triatomine species (Pérez et al., 1992; Panzera et al., 1995, 1997) and to detect intraspecific variation (Panzera et al., 1992). This group of heteropteran insects exhibits holocentric chromosomes, which do not have a morphologically differentiated centromere. Previous cytogenetic information concerning T. brasiliensis is mainly restricted to its diploid chromosome number $(2 \mathrm{n}=20$ autosomes plus $\mathrm{XY}$ in the males and XX in the females)(Schreiber \& Pellegrino, 1950; Schreiber et al., 1967).

\section{Material and methods}

\section{Material analyzed}

The origins of the populations studied in this report are shown in Table 1. At least three individuals per population were analyzed.

\section{Cytogenetic studies}

\section{- Chromosome preparations and banding procedures}

Gonads (testes and ovaries) were fixed in ethanol-acetic acid (3:1) and softened in a $45 \%$ aqueous solution of acetic acid. Part of the material was used in squashes and stained with lacto-acetic orcein for meiotic descriptions. The remaining material was studied using the C-banding technique according to Pérez et al. (1997), to observe the distribution and behavior of C-heterochromatin during mitosis and meiosis. 
Collection sites of the different populations of Triatoma brasiliensis studied in this report.

\begin{tabular}{llll}
\hline Population & State of Brazil & Locality & Habitat \\
\hline brasiliensis & Ceará & $\begin{array}{l}\text { Independência } \\
\text { Novo Oriente }\end{array}$ & $\begin{array}{l}\text { Intradomestic/Peridomestic/Sylvatic } \\
\text { Intradomestic } \\
\text { brasiliensis }\end{array}$ \\
$\begin{array}{l}\text { brasiliensis } \\
\text { brasiliensis }\end{array}$ & Pernambuco & Simplício Mendes & Intradomestic/Peridomestic \\
macromelasoma & Rio Grande do Norte & Cerra Nova & Intradomestic/Peridomestic \\
melanica & Pernambuco & Petrolina & Laboratory, 3rd generation. \\
juazeiro & Minas Gerais & Espinosa & Laboratory, 3rd generation. \\
& Bahia & Juazeiro & Laboratory, 3rd generation. \\
\hline
\end{tabular}

\section{- Cytogenetic markers}

We used several cytogenetic markers according to Pérez et al. (1992). Those traits based on relative chromosome size, such as autosomal size and autosomes versus sex chromosomes, were assessed by observing first and second meiotic metaphases.

The amount of autosomal C-heterochromatin was estimated using specific software (Image Pro-Plus - Media Cybernetics, Maryland, USA). For each individual at least three metaphase plates were analyzed.

\section{Results}

No cytogenetic differences were observed between the four chromatic forms of T. brasiliensis. All the individuals present the same diploid chromosome number $(2 \mathrm{n}=20 \mathrm{~A}+\mathrm{XY}$ oे, $\mathrm{XX}$ ㅇ $)$. The chromosome complement shows a small variation in the autosomal size, although two pairs of autosomes are slightly larger than the rest (Figure 1). The sex chromosomes, $\mathrm{Y}$ and $\mathrm{X}$, exhibit an intermediate size and the $\mathrm{Y}$ chromosome is slightly larger than the $\mathrm{X}$ chromosome (Figures 1d and 1e).

With C-banding, all autosomal pairs show a C-heterochromatic region at one or both chromosomal ends. Only one autosomal pair presents a small interstitial C-band (arrowheads Figure 1f). Although there is some variation in the size and distribution of heterochromatin among the individuals, this was not correlated with their chromatic pattern. The Y chromosome is totally heterochromatic (Figure 1f) while the $\mathrm{X}$ chromosome is $\mathrm{C}$-negative. The amount of autosomal C-heterochromatin represents about $25-32 \%$ of the total autosomal complement.
During early male meiotic prophase, one heteropycnotic chromocenter (arrows) and several heteropycnotic dots scattered throughout the nucleus are observed (Figures la and $1 b)$. The pachytene stage is very specific and allows a clear identification of this species. In this stage, all bivalents are rather separated and present a terminal C-heterochromatic dot in one or both chromosomal ends (Figure 1a). The diffuse stage is characterized by a significant increase in nuclear size (Figure 1b). During diplotene, associated XY sex chromosomes remain heteropycnotic, and they are often attached to the terminal heteropycnotic regions of one or two autosomal bivalents (arrows Figure 1c).

The first and second meiotic metaphases present the typical ring chromosomal disposition characteristic of Triatominae (Figures 1d and 1e, respectively). At first anaphase, the two chromatids of each sex chromosome separate to opposite poles (postreductional segregation), so the first meiotic division is equational for the sex chromosomes, as in other Hemiptera. At second meiotic metaphase, the autosomes are seen in the periphery of the spindle with the $X$ and $Y$ chromosomes in the center of the ring forming a pseudobivalent (Figure 1e). The $\mathrm{X}$ and $\mathrm{Y}$ chromatids segregate to opposite poles during anaphase II. The second division is thus reductional for the sex chromosomes. Table 2 summarizes the cytogenetic features observed in T. brasiliensis populations.

\section{Discussion}

The subfamily Triatominae presents little variation in chromosome numbers, which range between 21 and 25 chromosomes in the males (Panzera et al., 1998). Variation is due almost 
Triatoma brasiliensis. $2 \mathrm{n}=22=20 \mathrm{~A}+\mathrm{XY} \delta / \mathrm{XX}+$. (A-E) Male meiosis. (F) Male mitotic prometaphase.

a) Pachytene. C-banding. This stage is diagnostic for the identification of this species. The ten autosomal bivalents can be counted and identified, which is very unusual in Triatoma species. Bar $=10 \mathrm{~mm}$.

b) Diffuse stage. C-banding. This stage is characterized by a significant increase in nuclear size. A large heteropycnotic chromocenter is observed (arrow) and multiple dots are spread in the nucleus.

c) Diplotene stage. Orcein stain. Both heteropycnotic sex chromosomes (XY) remain associated and attached to two autosomal bivalents (arrows).

d) First meiotic metaphase. Orcein stain. The ten autosomal bivalents and two sex chromosomes are clearly observed. e) Second meiotic metaphase. Orcein stain. Typical ring disposition of autosomes with both sex chromosomes in the center. f) Spermatogonial prometaphase. C-banding. All autosomal pairs have C-heterochromatic blocks at one or both chromosomal ends. Furthermore, one autosomal pair present a small interstitial C-band (arrowheads). The $\mathrm{Y}$ chromosome is totally heterochromatic (arrow), while the $\mathrm{X}$ chromosome is C-negative. Bar $=10 \mathrm{~mm}$.
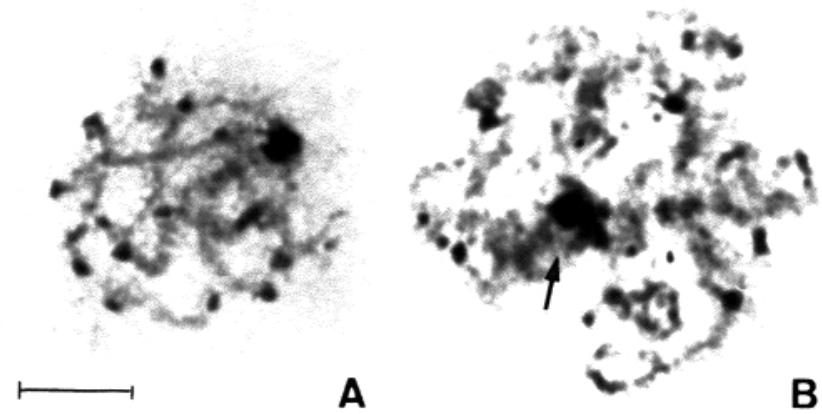

A

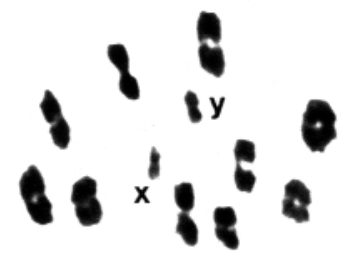

D

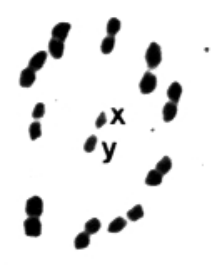

E

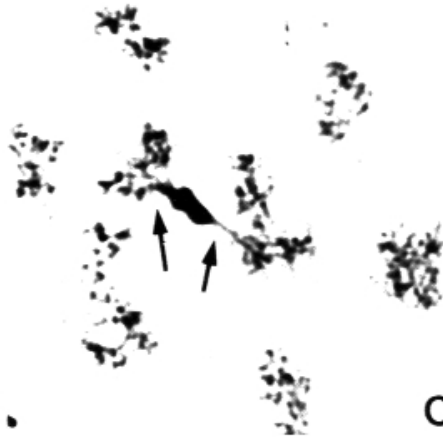

C exclusively to different sexual mechanisms (XY, $\mathrm{X} 1 \mathrm{X} 2 \mathrm{Y}$, and X1X2X3Y). All the individuals of $T$. brasiliensis analyzed show the most frequent and typical chromosome number of the genus Triatoma: $2 \mathrm{n}=22$ (composed by 20 autosomes and two sex chromosomes) (Ueshima, 1966). Despite the homogeneity in chromosome number, the banding pattern and chromosome behavior during the male meiotic process reveal great variability between the species and even among populations for the same species. For these reasons they are generally species-specific and work as diagnostic characters for species identification (Panzera et al., 1998). Table 2 describes, for the first time, the cytogenetic fea- tures of T. brasiliensis. The pachytene stage shows distinct and specific characters of this species, which differ from those observed in all other triatomine species (except for Triatoma petrochiae, see below).

In some species, cytogenetic studies also revealed intraspecific variations. We detected an extensive polymorphism of C-heterochromatin in natural populations of Triatoma infestans (Panzera et al., 1992) and Triatoma sordi$d a$ (Panzera et al., 1997). In the latter species, the chromosome differences led to the revalidation of Triatoma garciabesi, subsequently confirmed by isoenzymatic (Noireau et al., 1998) and morphometric (Jurberg et al., 1998) 
Cytogenetic traits recorded for the four chromatic patterns of Triatoma brasiliensis.

\begin{tabular}{ll}
\hline Autosomal number & 20 \\
Sex mechanism & $X Y \AA / X X \uparrow$ \\
Relative autosomal size & Small variation \\
Relative size of the sex chromosomes between them & $X<Y$ \\
Relative size of sex chromosomes versus autosomes & Medium \\
Constitution of meiotic chromocenter / s & Sex chromosomes plus autosomes \\
Number of autosomal pairs with C-blocks & 10 \\
Amount (\%) autosomal C-heterochromatin & $25-32 \%$ \\
Location of autosomal C-blocks & One or both chromosomal ends \\
X with C-bands & Interstitial position in one pair. \\
Special characteristic & No \\
\hline
\end{tabular}

markers. However, in T. brasiliensis, we could not detect any cytogenetic differences among specimens with distinct color patterns. This does not rule out the taxonomic status of the four chromatic forms as populations, subspecies, or even species. The morphological, ecological, and molecular differences observed between the chromatic forms of $T$. brasiliensis (see Introduction) indicate that the populations of this species are in a differentiation process that does not involve their chromosomal organization. This differentiation might lead to a speciation process, which in Triatominae seems to be a rapid process mainly driven by ecological factors (Dujardin et al., 1999).

Our previous results indicate that a given triatomine species can show variable chromosome evolution rate, which may be due to diverse divergence times, different ecological pressures on their populations, or some intrinsic property of their karyotype. Our results can

\section{Acknowledgments}

This work was partially supported by FNS (Fundação Nacional de Saúde, Brazil), CONICYT (Fondo Clemente Estable, Project 2034) from Uruguay, and through the ECLAT (European Community \& Latin American Network on Biology and Control of Triatomines) research network using funds from the AVINA Foundation (Switzerland) and projects IC18 CT96-0042 and ERBIC 18 CT 98-0366 from the European Community. be extended to groups of closely related species. Triatoma petrochiae, a species closely related and morphologically similar to the brasiliensis group, presents the same chromosome characteristics described in Figure 1 and Table 2 for $T$. brasiliensis. Isoenzymatic data not only confirmed the specific status of both species but also suggested they have been evolving independently for considerable time (Monteiro et al., 1998). On the contrary, other groups of closely related species show clear chromosomal divergences such as the ones that belong to infestans subcomplex (T. infestans, Triatoma platensis, and Triatoma delpontei) and the sordida subcomplex (T. sordida, Triatoma patagonica, and T. guasayana) (Panzera et al., 1995 and 1997 respectively). All this is evidence that several groups of Triatoma species show different chromosome evolution rates that may reflect adaptation to different environments or some intrinsic property of their chromosome complement.

\section{References}

COSTA, J., 1999. The synanthropic process of Chagas Disease vectors in Brazil, with special attention to Triatoma brasiliensis Neiva, 1911 (Hemiptera, Reduviidae, Triatominae). Population, genetical, ecological and epidemiological aspects. Memórias do Instituto Oswaldo Cruz, 94:239-241.

COSTA, J.; BARTH, O. M.; MARCHON-SILVA, V.; FREITAS-SIBAJEV, M. G. R.; PIRES, M. Q. \& PACHECO, R. S., 1996. Estudos isoenzimáticos detectam variação intra-específica em Triatoma brasiliensis Neiva, 1911 (Reduviidae, Triatominae). Revista da Sociedade Brasileira de Medicina Tropical, 29:129. 
COSTA, J.; FREITAS-SIBAJEV, M. G. R.; MARCHONSILVA, V.; PIRES, M. Q. \& PACHECO, R. S., 1997a. Isoenzymes detect variation in populations of Triatoma brasiliensis (Hemiptera: Reduviidae: Triatominae). Memórias do Instituto Oswaldo Cruz, 92:459-464.

COSTA, J.; BARTH, O. M.; MARCHON-SILVA, V.; ALMEIDA, C. E.; FREITAS-SIBAJEV, M. G. R. \& PANZERA, F., 1997b. Morphological studies on the Triatoma brasiliensis Neiva, 1911 (Hemiptera, Reduviidae, Triatominae). Memórias do Instituto Oswaldo Cruz, 92:493-498.

COSTA, J.; RIBEIRO-DE-ALMEIDA, J.; BRITTO, C.; DUARTE, R.; MARCHON-SILVA, V. \& PACHECO, R. S., 1998. Ecotopes, natural infection and trophic resources of Triatoma brasiliensis (Hemiptera, Reduviidae, Triatominae). Memórias do Instituto Oswaldo Cruz, 93:7-13.

DUJARDIN, J. P.; PANZERA, F. \& SCHOFIELD, C. J., 1999. Triatominae as a model of morphological plasticity under ecological pressure. Memórias do Instituto Oswaldo Cruz, 94:223-228.

GALVÃO, A. B., 1956. Triatoma brasiliensis macromelasoma n. subsp. (Hemiptera-Reduviidae, Triatominae). Revista Brasileira de Malariologia e Doenças Tropicais, 7:455-457.

JURBERG, J.; GALVÃO, C.; LENT, H.; MONTEIRO, F.; MACEDO, C.; PANZERA, F. \& PEREZ, R., 1998. Revalidação de Triatoma garciabesi Carcavallo, Cichero, Martínez, Prosen \& Ronderos (1967) (Hemiptera-Reduviidae). Entomología y Vectores, 5: 107-122.

LENT, H. \& WYGODZINSKY, P., 1979. Revision of the Triatominae (Hemiptera, Reduviidae), and their significance as vectors of Chagas' Disease. Bulletin of the American Museum of Natural History, 163:127-520.

MONTEIRO, F. A.; COSTA, J. \& SOLE-CAVA, A. M., 1998. Genetic confirmation of the specific status of Triatoma petrochii (Hemiptera:Reduviidae:Triatominae). Annals of Tropical Medicine \& Parasitology, 92:897-900.

MONTEIRO, F. A.; COSTA, J. \& BEARD, C. B., 1999. High levels of mitochondrial DNA sequence divergence among Triatoma brasiliensis Neiva, 1911 populations (Hemiptera:Reduviidae:Triatominae). Memórias do Instituto Oswaldo Cruz, 94 (Sup. 2):244.

NOIREAU, F; GUTIERREZ, T.; ZEGARRA, M.; FLORES, R.; BRENIERE, F.; CARDOZO, L. \& DUJARDIN, J. P., 1998. Cryptic speciation in Triatoma sordida (Hemiptera-Reduviidae) from the Bolivian Chaco. Tropical Medicine and International Health, 3:364-372.
PANZERA, F.; ALVAREZ, F.; SANCHEZ-RUFAS, J.; PEREZ, R.; SUJA, J. A.; SCVORTZOFF, E.; DUJARDIN, J. P.; ESTRAMIL, E. \& SALVATELLA, R., 1992. C-heterochromatin polymorphism in holocentric chromosomes of Triatoma infestans (HemipteraReduviidae). Genome, 35:1068-1074.

PANZERA, F.; PEREZ, R.; PANZERA, Y.; ALVAREZ, F.; SCVORTZOFF, E. \& SALVATELLA, R., 1995. Karyotype evolution in holocentric chromosomes of three related species of triatomines (HemipteraReduviidae). Chromosome Research, 3:143-150.

PANZERA, F.; HORNOS, S.; PEREIRA, J.; CESTAU, R.; CANALE, D.; DIOTAIUTI, L.; DUJARDIN, J. P. \& PEREZ, R., 1997. Genetic variability and geographic differentiation among three species of triatomine bugs (Hemiptera-Reduviidae). American Journal of Tropical Medicine and Hygiene, 57:732739 .

PANZERA, F; SCVORTZOFF, E.; PEREZ, R.; PANZERA, Y.; HORNOS, S.; CESTAU, R.; NICOLINI, P.; DELGADO, V.; ALVAREZ, F.; MAZZELLA, M.; COSSIO, G.; MARTINEZ, M. \& SALVATELLA, R., 1998. Cytogenetics of Triatomines. In: Atlas of Chagas' Disease Vectors in the Americas (R. U. Carcavallo, I. Galíndez-Girón, J. Jurberg \& H. Lent, eds.), pp. 621-664, Rio de Janeiro: Editora Fiocruz.

PEREZ, R.; PANZERA, Y.; SCAFIEZZO, S.; MAZZELLA, M. C.; PANZERA, F.; DUJARDIN, J. P. \& SCVORTZOFF, E., 1992. Cytogenetics as a tool for triatomine species distinction (Hemiptera-Reduviidae). $\mathrm{Me}$ mórias do Instituto Oswaldo Cruz, 87:353-361.

PEREZ, R.; PANZERA, F.; PAGE, J.; SUJA, J. \& RUFAS, J., 1997. Meiotic behaviour of holocentric chromosomes: Orientation and segregation of autosomes in Triatoma infestans (Heteroptera). Chromosome Research, 5:47-56.

SCHREIBER, G. \& PELLEGRINO, J., 1950. Eteropicnosi di autosomi come possible meccanismo di speciazione (Ricerche citologiche su alcuni Emitteri neotropici). Sciencia Genetica, 3:215-226.

SCHREIBER, G.; CARVALHO, H. C. \& ESPÍNOLA, H. N., 1967. Genetics of Triatoma and other vector species. In: Genetics of Insect Vectors of Disease ( $\mathrm{J}$. W. Wright \& R. Pal, eds.), pp. 441-456, Amsterdam: Elsevier.

SILVEIRA, A. C.; FEITOSA, V. R. \& BORGES, R., 1984. Distribução de triatomíneos capturados no ambiente domiciliar, no período de 1975/83, Brasil. Revista Brasilera de Malariologia e Doenças Tropicais, 36:15-312.

UESHIMA, N., 1966. Cytotaxonomy of the Triatominae (Hemiptera-Reduviidae). Chromosoma, 18:97-122. 